\title{
KEMAMPUAN PENALARAN MATEMATIS SISWA KELAS VIII MTS ISLAMIYAH MEDAN MELALUI PENDEKATAN OPEN-ENDED
}

\author{
Ade Evi Fatimah \\ Prodi Pendidikan Matematika STKIP Pelita Bangsa Binjai \\ eviade997@gmail.com
}

\begin{abstract}
This research is a Classroom Action Research which aims to improve the mathematical reasoning ability of students of class VIII Mts Islamiyah Medan through the Open-Ended approach. The subjects in this study were all students of class VIII-1 MTs Islamiyah Medan, totaling 24 students. This research was conducted in 2 cycles, namely cycle I and II, each of which consisted of two meetings. The instruments used in this study were observation guidelines for implementing learning with the Open-Ended approach, cycle tests to measure students' mathematical reasoning abilities towards learning mathematics with the Open-Ended approach, interview guidelines and documentation. Data from observations, tests, and questionnaires were analyzed quantitatively which was strengthened by the results of interviews and descriptive qualitative documentation. The results showed that the mathematical reasoning ability of students in class VIII-1 MTs Islamiyah Medan increased from cycle I to cycle II after learning was carried out with the Open-Ended approach. This is shown by as many as 20 students or $83.3 \%$ experienced an increase in mathematical reasoning ability based on the total score of aspects of mathematical reasoning ability. The average percentage of test scores increased from $66.6 \%$ in the first cycle to $83.3 \%$ in the second cycle and in the high category. Based on observations of the implementation of learning with the Open-Ended approach is good and in accordance with the characteristics of the Open-Ended Approach. Based on the results of interviews and questionnaire results data student responses to mathematics learning in relation to mathematical reasoning abilities, increased from cycle I to cycle II.
\end{abstract}

Keywords: Mathematical Reasoning Ability, Open-Ended Approach.

\begin{abstract}
Abstrak. Penelitian ini merupakan Penelitian Tindakan Kelas yang bertujuan untuk meningkatkan kemampuan penalaran matematis siswa kelas VIII Mts Islamiyah Medan melalui pendekatan Open-Ended. Subjek dalam penelitian ini adalah seluruh siswa kelas VIII1 MTs Islamiyah Medan yang berjumlah 24 siswa. Penelitian ini dilaksanakan dalam 2 siklus, yaitu siklus I dan II yang masing-masing terdiri dari dua pertemuan. Instrumen yang digunakan dalam penelitian ini adalah pedoman observasi pelaksanaan pembelajaran dengan pendekatan Open-Ended, tes siklus untuk mengukur kemampuan penalaran matematis siswa terhadap pembelajaran matematika dengan pendekatan Open-Ended, pedoman wawancara dan dokumentasi. Data dari hasil observasi, tes dan angket dianalisis secara kuantitatif yang diperkuat dengan hasil wawancara dan dokumentasi secara deskriptif kualitatif. Hasil penelitian menunjukkan bahwa kemampuan penalaran matematis siswa kelas VIII-1 MTs Islamiyah Medan mengalami peningkatan dari siklus I ke siklus II setelah dilaksanakan pembelajaran dengan pendekatan Open-Ended. Hal ini ditunjukkan oleh sebanyak 20 siswa atau 83,3\% mengalami peningkatan kemampuan penalaran matematis berdasarkan skor total aspek kemampuan penalaran matematis. Persentase rata-rata nilai tes mengalami peningkatan dari 66,6\% pada siklus I menjadi 83,3\% pada siklus II dan dalam kategori tinggi. Berdasarkan hasil observasi pelaksanaan pembelajaran dengan pendekatan Open-Ended sudah baik dan sesuai dengan karakteristik Pendekatan Open-Ended. Berdasarkan hasil wawancara dan data hasil angket respon siswa terhadap pembelajaran matematika kaitannya dengan kemampuan penalaran matematis, mengalami peningkatan dari siklus I ke siklus II.
\end{abstract}

Kata Kunci: Kemampuan Penalaran Matematis, Pendekatan Open-Ended.

\section{PENDAHULUAN}

Dalam sistem pendidikan, keberhasilan dan kualitas siswa merupakan subyek yang menjadi fokus utama. Berkenaan dengan itu, salah satu pelajaran yang penting dalam 
menunjang peningkatan keberhasilan dan kualitas para siswa adalah pelajaran matematika. Guru sebagai tenaga pendidik tetap harus berpikir keras bagaimana mengemas materi pelajaran matematika agar menjadi menarik dan mudah dipahami oleh siswa. Dalam pembelajaran matematika, siswa selalu dihadapkan pada berbagai masalah. Untuk memecahkan masalah tersebut siswa haruslah mempunyai daya nalar agar bisa berpikir logis dan sistematis. Turmudi (2008) mengatakan bahwa kemampuan penalaran matematis merupakan suatu kebiasaan otak seperti halnya kebiasaan lain yang harus dikembangkan secara konsisten menggunakan berbagai macam konteks, mengenal penalaran dan pembuktian merupakan aspek-aspek fundamental dalam matematika. Selanjutnya, Sumartini (2015) mengatakan bahwa penalaran merupakan suatu kegiatan atau proses berpikir untuk menarik kesimpulan atau membuat pernyataan baru yang didasarkan pada pernyataan sebelumnya dan kebenarannya telah dibuktikan.

Pentingnya daya nalar siswa dalam pembelajaran matematika juga disebutkan oleh NCTM (2000:67). Selanjutnya Depdiknas (2006) juga menjelaskan bahwa pentingnya menggunakan penalaran pada pola dan sifat, melakukan manipulasi matematika dalam membuat generalisasi, menyusun bukti atau menjelaskan gagasan dan pernyataan matematika. Dengan demikian dapat disimpulkan bahwa dengan penalaran matematis, siswa dapat melatih cara berpikir dan bernalar, membuat beberapa dugaan atau hipotesis kemudian menyusun bukti yang ada dan mengeksplor ide-ide matematika untuk memanipulasi permasalahan matematika serta dapat menarik suatu kesimpulan dengan benar dan tepat. Oleh karena itu guru harus berperan aktif dalam menumbuhkan kemampuan penalaran matematis siswa.

Akan tetapi, pentingnya kemampuan penalaran matematis dalam pembelajaran matematika belum disadari sebagian besar siswa di Indonesia. Hal ini didukung dengan pendapat Rosnawati (2011) yang menyatakan bahwa rata-rata persentase yang paling rendah yang dicapai oleh siswa Indonesia adalah dalam domain kognitif pada level penalaran yaitu $17 \%$. Hal yang serupa juga dijumpai di sekolah MTs Islamiyah Medan, kemampuan penalaran matematis siswa kelas VIII masih rendah, dari hasil observasi awal diperoleh bahwa sebesar $79 \%$ siswa masih dikategorikan mempunyai penalaran yang rendah.

Rendahnya kemampuan penalaran matematis siswa salah satunya dipengaruhi oleh metode pembelajaran yang digunakan oleh guru. Berdasarkan hasil penelitian yang dilakukan oleh Lestari, dkk (2016) yang mengemukakan bahwa penalaran matematika siswa SMP Negeri 8 Palembang masih tergolong rendah. Hal ini disebabkan oleh beberapa faktor, diantaranya guru terlalu berkosentrasi pada hal-hal yang prosedural dan mekanistik seperti pembelajaran berpusat pada guru, konsep matematika sering disampaikan secara informatif, dan siswa dilatih menyelesaikan tanpa pemahaman yang mendalam.

Salah satu upaya dalam menyikapi rendahnya penalaran berfikir matematis siswa bisa ditempuh melalui pemilihan pembelajaran. Pembelajaran yang diharapkan adalah pembelajaran yang tepat, yang dapat memberikan kesempatan yang luas kepada siswa untuk berfikir serta mengembangkan dan mengkomunikasikan ide-ide serta informasi sehingga tujuan pembelajaran dapat tercapai. Wahyudin (2008) mengatakan bahwa salah satu aspek penting dari perencanaan bertumpu pada kemampuan guru untuk mengantisipasi kebutuhan dan materi-materi dan model-model yang dapat membantu para siswa untuk mencapai tujuan pembelaran. Selanjutnya Sagala (2011) juga menyatakan bahwa guru harus mempunyai metode dalam pembelajaran sebagai strategi yang dapat memudahkan siswa untuk menguasai ilmu pengetahuan yang diberikan.

Salah satu model pembelajaran yang yang menjadi alternatif pilihan yang diduga mampu meningkatkan kemampuan penalaran matematis siswa adalah pendekatan OpenEnded. Menurut Shimada dan Becker (1997) munculnya pendekatan open-ended berawal 
dari pandangan bagaimana menilai kemampuan siswa secara objektif kemampuan berfikir tingkat tinggi matematika, rangkaian pengetahuan, keterampilan, konsep-konsep, prinsipprinsip atau aturan-aturan biasanya diberikan kepada siswa dalam langkah sistematis. Menurut Pehkonen (1999) menjelaskan bahwa suatu masalah dikatakan terbuka, apabila starting point atau tujuan masalah tersebut tidak secara jelas diberikan. Lebih lanjut dia mengatakan bahwa masalah Open-Ended dapat diklasifikasikan menjadi beberapa macam, yaitu: (1) investigasi (di mana starting point diberikan), (2) problem posing (atau problem finding atau problem formulating), (3) real-life situation (masalah yang mana akar permasalahannya berasal dari kehidupan sehari-hari), (4) projects (yaitu entitas penelitian yang lebih besar, yang membutuhkan kerja mandiri), (5) problem fields (atau problem sequences atau problem domains, suatu masalah yang dihubungkan dengan sekumpulan masalah kontekstual), (6) problems without a question, dan (7) problem variations ("whatif'--method). Selanjutnya Hino (2007) masalah terbuka (Open-Ended problem) adalah suatu masalah yang diformulasikan sedemikian sehingga memiliki beberapa jawaban yang benar. Jadi dalam pendekatan Open-Ended terdapat keterbukaan dalam kegiatan siswa, konten matematika, dan dalam interaksi antara siswa dan konten matematika sehingga OpenEnded merupakan suatu pendekatan pembelajaran yang memberikan kesempatan kepada siswa untuk menyelesaikan masalah dengan berbagai cara dan jawaban benar yang lebih dari satu, kemudian didiskusikan untuk saling membandingkan hasil pekerjaan. Terdapatnya keterbukaan dalam Open-Ended dapat meningkatkan kemampuan penalaran matematis siswa karena mempunyai banyak cara penyelesaian yang benar dan mempunyai banyak jawaban yang benar, sehingga siswa mampu mengembangkan ide-ide matematika sehingga menimbulkan kemampuan berpikir tingkat tinggi dengan mengembangkan masalah baru dari masalah yang ada.

Berdasarkan uraian di atas, penulis akan berupaya meningkatkan kemampuan penalaran matematis siswa kelas VIII dengan menggunakan pendekatan Open-Ended di sekolah MTs Islamiyah Medan. Adapun permasalahan yang dikemukakan dalam penelitian ini adalah apakah penerapan pendekatan pembelajaran Open-Ended dapat meningkatkan kemampuan penalaran matematis siswa kelas VIII MTs Islamiyah Medan?

\section{METODE}

Penelitian ini merupakan penelitian tindakan kelas (PTK). PTK ini dilaksanakan di sekolah MTs Islamiyah Medan dengan tujuan meningkatkan kemampuan penalaran matematis siswa kelas VIII pada materi SPLDV melalui tindakan penerapan pendekatan pembelajaran Open-Ended. Subjek penelitian ini adalah siswa kelas VIII-1 MTs Islamiyah Medan Tahun Pelajaran 2018/2019 dengan jumlah 24 siswa, sedangkan objek penelitian ini adalah keseluruhan proses dan hasil pembelajaran matematika melalui pendekatan pembelajaran Open-Ended sebagai upaya meningkatkan kemampuan penalaran matematis siswa kelas VIII-1 MTs Islamiyah Medan.

Desain penelitian yang digunakan adalah bentuk siklus yang mengacu pada model Kemmis dan Mc Taggrat. Rencana penelitian tindakan kelas ini, terdiri dari 2 siklus. Tiap siklus dilaksanakan sesuai dengan perubahan yang ingin dicapai, seperti apa yang telah didesain dalam faktor yang diselidiki. Desain yang digunakan tersebut dapat dilihat pada Gambar 1 di bawah ini: 


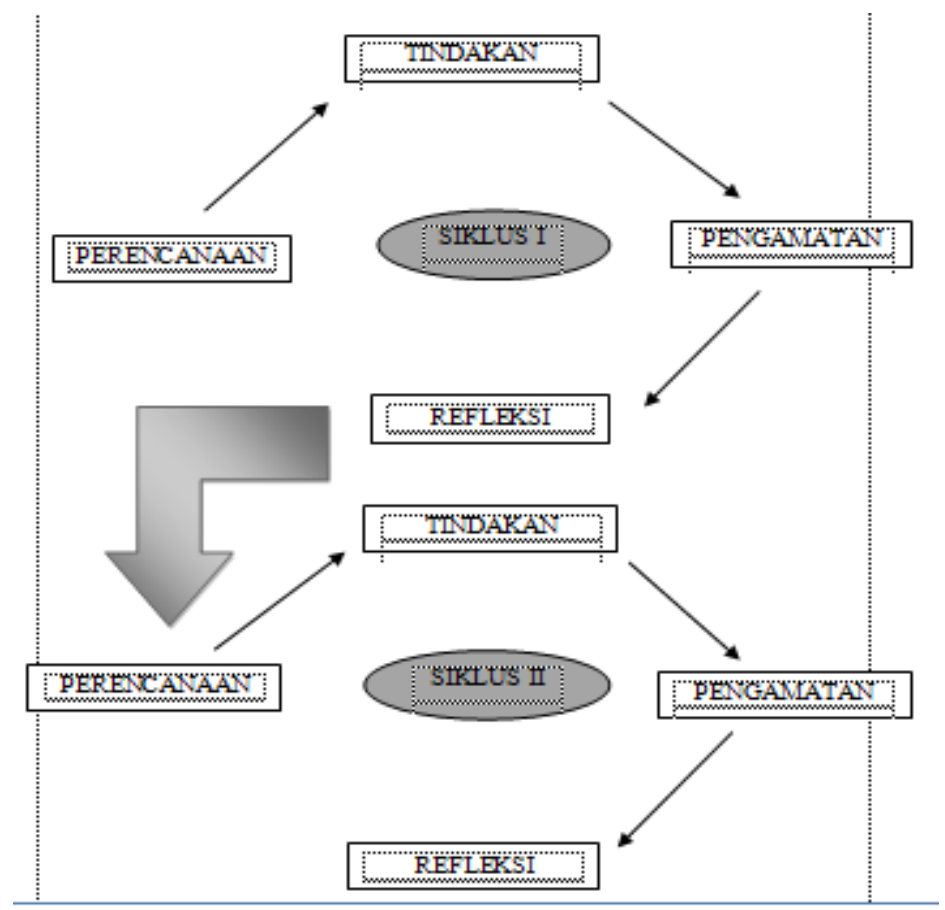

Gambar 1. Desain Penelitian Menurut Kemmis dan Mc Taggart (Arikunto, 2006)

Menurut Arikunto (2006) Secara garis besar dalam penelitian tindakan kelas terdapat empat tahapan yang lazim dilalui yaitu, perencanaan (planning), pelaksanaan (acting), pengamatan (observing), dan refleksi (reflecting).

Penelitian ini dilakukan dalam beberapa siklus (siklus I, II dan seterusnya) untuk melihat peningkatan kemampuan penalaran matematis siswa melalui pendekatan OpenEnded. Siklus akan dihentikan jika pembelajaran matematika melalui pendekatan OpenEnded telah mencapai indikator keberhasilan. Indikator keberhasilan pada penelitian ini ditentukan sebagai berikut:

1. Keterlaksanaan pembelajaran melalui pendekatan Open-Ended berada dalam kategori sangat baik.

2. Berdasarkan hasil observasi kemampuan penalaran matematis, kemampuan penalaran matematis siswa kelas VIII-1 meningkat dari siklus I ke siklus selanjutnya mencapai kategori baik.

3. Adanya peningkatan kemampuan komunikasi matematika siswa setelah diterapkan pendekatan Open-Ended dari siklus I ke siklus II dengan membandingkan antara skor tes pada siklus I dan skor tes pada siklus II dengan kriteria minimal $60 \%$ dari jumlah siswa mengalami peningkatan di atas KKM pada skor total indikator kemampuan penalaran matematika.

\section{HASIL DAN PEMBAHASAN}

\section{Hasil}

\section{Deskripsi Hasil Penelitian pada Siklus I}

Kegiatan pembelajaran pada siklus I dilakukan sebanyak dua kali pertemuan. Pada tahapan ini siswa diberikan tes awal dengan tujuan untuk melihat kemampuan awal siswa. Dari hasil tes diagnostik tersebut diperoleh 4 siswa $(16,6 \%)$ dengan kemampuan penalaran yang berkategori baik (nilainya $\geq 75$ ), sedangkan 20 orang lainnya $(83,3 \%$ ) berkategori rendah . Dari 24 orang siswa terdapat 2 orang siswa memperoleh nilai antara 90-100 dan siswa tersebut termasuk siswa berkemampuan sangat tinggi, 4 orang siswa memperoleh nilai antara 65-79 dan siswa tersebut termasuk siswa berkemampuan sedang, 17 orang 
siswa memperoleh nilai antara 55-64 dan siswa tersebut termasuk siswa berkemampuan rendah sedangkan 2 siswa lainnya memperoleh nilai $\leq 54$ dikategorikan siswa berkemampuan sangat rendah. Nilai rata-rata kelas yang diperoleh dari 24 orang siswa pada tes awal ini 36,25. Hasil selengkapnya dapat dilihat pada Tabel 1 berikut:

Tabel 1. Deskripsi Tingkat Kemampuan Penalaran Matematis Siswa pada Tes Awal

\begin{tabular}{|c|c|c|c|c|}
\hline $\begin{array}{l}\text { Persentase } \\
\text { Penguasaan }\end{array}$ & $\begin{array}{c}\text { Tingkat } \\
\text { Kemampuan }\end{array}$ & $\begin{array}{c}\text { Banyak } \\
\text { Siswa }\end{array}$ & $\begin{array}{c}\text { Persentase } \\
\text { Jumlah Siswa }\end{array}$ & $\begin{array}{c}\text { Rata-rata } \\
\text { Skor } \\
\text { Kemampuan }\end{array}$ \\
\hline $90 \%-100 \%$ & Sangat tinggi & 0 & - & \multirow{5}{*}{$\begin{array}{c}61,25 \\
(16,6 \%)\end{array}$} \\
\hline $80 \%-89 \%$ & Tinggi & 1 & $4,1 \%$ & \\
\hline $65 \%-79 \%$ & Sedang & 4 & $20,7 \%$ & \\
\hline $55 \%-64 \%$ & Rendah & 17 & $91,6 \%$ & \\
\hline $0 \%-54 \%$ & Sangat rendah & 2 & $100 \%$ & \\
\hline & $\Sigma$ & 24 & $100 \%$ & \\
\hline
\end{tabular}

Dari Tabel 1 dapat dilihat bahwa masih banyak siswa dengan tingkat kemampuan rendah sehingga perlu diberikan alternatif pemecahan I (rencana tindakan I), yait :

a. Guru merencanakan skenario pembelajaran pembelajaran dengan menerapkan pendekatan pembelajaran Open-Ended.

b. Guru menyusun Lembar Aktivitas Siswa (LAS) sesuai dengan pokok bahasan SPLDV.

c. Guru menyiapkan soal-soal untuk tes kemampuan penalaran I.

d. Guru mempersiapkan lembar observasi untuk mengamati situasi dan kondisi kegiatan pembelajaran.

Rencana tindakan pada siklus I tersebut kemudian dilaksanakan dengan menerapkan pendekatan Open-Ended yang dilakukan sebanyak dua kali pertemuan. Kemudian setelah itu dilakukan observasi dan wawancara I. Observasi dilakukan oleh guru matematika kelas VIII-1 MTs Islamiyah Medan. Observasi dilakukan sejak permulaan pelaksanaan tindakan sampai berakhirnya pelaksanaan tindakan pembelajaran. Guru kelas mengamati tindakan peneliti selama mengajar dengan menerapkan pendekatan pembelajaran Open-Ended untuk meningkatkan kemampuan penalaran matematis siswa. Dari hasil observasi yang dilakukan, pengelolaan pembelajaran yang dilakukan sudah baik, namun masih perlu beberapa perbaikan, yaitu:

a. Guru belum menyampaikan tujuan pembelajaran dengan baik.

b. Guru masih kurang terampil dalam membuka pelajaran.

c. Penggunaan waktu yang masih kurang efektif, sehingga ada beberapa siswa yang tidak dapat menyelesaikan LAS karena kehabisan waktu.

Sedangkan untuk wawancara ditujukan kepada siswa kelas VIII-1 MTs Islamiyah Medan untuk mengetahui kesulitan-kesulitan yang dialami siswa dalam menyelesaikan tes kemampuan penalaran matematis. Dari hasil wawancara mengenai kesulitan siswa dalam menjawab soal yang diberikan oleh guru diperoleh beberapa hal yang menyebabkan siswa mengalami kesulitan seperti:

a. Siswa kesulitan dalam membuat analogi

b. Siswa kesulitan membuat penjelasan dengan model matematika

c. Siswa mengalami kesulitan membuat pola dan menganalisis karena waktunya sedikit

d. Siswa kesulitan dalam menarik kesimpulan

Setelah pelaksanaan tindakan I maka diperoleh hasil tes kemampuan penalaran matematis siswa di kelas VIII-1 MTs Islamiyah Medan, yaitu terdapat 8 siswa yang memiliki nilai $<75$ yang berarti tingkat kemampuan penalarannya masih rendah. Dari data di atas, maka secara keseluruhan dapat diketahui bahwa kemampuan penalaran matematis 


\section{Kemampuan Penalaran Matematis Siswa Kelas VIII MTs Islamiyah Medan Melalui...}

siswa kelas VIII-1 MTs Islamiyah Medan sudah cukup baik, yaitu dengan persentase sebesar $70 \%$. Hal ini menunjukkan bahwa terjadi peningkatan kemampuan penalaran siswa sebesar 52,5\% dari kemampuan awal siswa yaitu sebesar 17,5\%. Namun hal ini belum mencapai target penelitian yaitu persentase kemampuan penalaran matematis siswa secara keseluruhan minimal 75\%. Hasil selengkapnya dapat dilihat pada Tabel 2 berikut:

Tabel 2. Deskripsi Tingkat Kemampuan Penalaran Matematis Siswa pada siklus I

\begin{tabular}{ccccc}
\hline $\begin{array}{c}\text { Persentase } \\
\text { Penguasaan }\end{array}$ & $\begin{array}{c}\text { Tingkat } \\
\text { Kemampuan }\end{array}$ & $\begin{array}{c}\text { Banyak } \\
\text { Siswa }\end{array}$ & $\begin{array}{c}\text { Persentase } \\
\text { Jumlah Siswa }\end{array}$ & $\begin{array}{c}\text { Rata-rata } \\
\text { Skor } \\
\text { Kemampuan }\end{array}$ \\
\cline { 1 - 4 } $90 \%-100 \%$ & Sangat tinggi & 3 & $12,5 \%$ & \\
\cline { 1 - 4 } $80 \%-89 \%$ & Tinggi & 5 & $33,3 \%$ & \\
\cline { 1 - 4 } $65 \%-79 \%$ & Sedang & 14 & $91,6 \%$ & \\
\cline { 1 - 4 } $55 \%-64 \%$ & Rendah & 2 & $100 \%$ & \\
\cline { 1 - 4 } $0 \%-54 \%$ & Sangat rendah & - & - & \\
\hline \multicolumn{2}{c}{$\Sigma$} & 24 & $100 \%$ & \\
\hline
\end{tabular}

Berdasarkan hasil observasi, wawancara dan data yang diperoleh dari tes kemampuan penalaran I, berikut ini diuraikan kegagalan dan keberhasilan dalam pelaksanaan tindakan pada siklus I, yaitu:

a. Pembentukan kelompok belajar berdasarkan penyebaran kemampuan siswa yang heterogen kurang menguntungkan karena ada beberapa siswa yang tidak ikut berpartisipasi aktif dalam diskusi.

b. Masih terdapat banyak kesalahan siswa dalam penyelesaian soal-soal pada LAS I.

c. Ada beberapa kelompok belajar siswa yang tidak berinisiatif untuk mempresentasikan hasil mereka di depan kelas sehingga dalam pelaksanaannya peneliti harus memilih secara acak kelompok belajar yang akan mempresentasikan hasil belajarnya.

d. Penyaji sebagai wakil kelompok, masih belum terampil dalam menyajikan hasil diskusi kelompoknya di depan kelas. Hal ini terlihat dari penampilan mereka pada saat mempresentasikan hasil diskusi tampak ragu-ragu, malu, dan suaranya kurang keras sehingga tidak terdengar dari belakang.

e. Selama penyaji menyampaikan hasil diskusi kelompoknya di depan kelas tidak ada satupun siswa (kelompok) yang mau memberikan tanggapan. Sehingga guru perlu memberikan motivasi kepada siswa agar aktif dalam diskusi.

f. Kemampuan penalaran matematis siswa masih rendah. Hal ini dapat dilihat dari masih rendahnya nilai tiap-tiap indikator kemampuan penalaran matematis siswa.

Disamping kegagalan yang terjadi selama pembelajaran, ternyata diperoleh peningkatan kemampuan penalaran masalah matematis siswa dalam menyelesaikan soalsoal SPLDV setelah diterapkannya pendekatan Open-Ended selama proses belajar mengajar berlangsung. Jumlah siswa yang telah mencapai ketuntasan belajar sebanyak 16 orang $(66,6 \%)$ dengan peningkatan ketuntasan belajar siswa mengalami kenaikan dengan rata-rata kelas mencapai 70,8. Karena kemampuan penalaran siswa belum mencapai target minimal kemampuan penalaran yaitu $75 \%$ dari siswa yang mengikuti tes mencapai nilai minimal 75 (sedang), maka perlu perbaikan program pengajaran sehingga tercapai target minimal penelitian. Karena ditemukan banyak kekurangan dalam pembelajaran selama siklus I dilaksanakan maka perlu diadakan perbaikan tindakan. Oleh karena itu, penelitian dilanjutkan ke siklus II. 


\section{Deskripsi Hasil Penelitian pada Siklus II}

Kegiatan pembelajaran pada siklus II dilakukan sebanyak dua kali pertemuan. Setelah diberikan tindakan II sebagai alternatif perbaikan dari siklus I maka hasil tes kemampuan penalaran matematis siswa yang diperoleh adalah tidak terdapat siswa dengan tingkat kemampuan penalaran yang sangat rendah, terdapat 11 siswa $(45,8 \%)$ dengan tingkat kemampuan penalaran sedang, 9 siswa (37,5\%) dengan tingkat kemampuan penalaran tinggi, serta 4 siswa $(16,7 \%)$ dengan tingkat kemampuan penalaran sangat tinggi. Secara keseluruhan, kemampuan penalaran matematis siswa yang telah mencapai ketuntasan belajar sebanyak 20 orang dengan persentase sebesar 83,3\%. Dalam hal ini terlihat bahwa terjadi peningkatan rata-rata kemampuan pemecahan masalah antara siklus I dan siklus II. Pada siklus I persentase rata-rata kemampuan pemecahan masalah siswa adalah $66.6 \%$ sedangkan pada siklus II persentase rata-rata kemampuan pemecahan masalah siswa adalah $83,3 \%$. Hal ini berarti telah mencapai target penelitian yaitu minimal $75 \%$ siswa yang mengikuti ujian mencapai ketuntasan belajar (nilai minimal 75). Hasil selengkapnya dapat dilihat pada Tabel 3 berikut:

Tabel 3. Deskripsi Tingkat Kemampuan Penalaran Matematis Siswa pada siklus I

\begin{tabular}{ccccc}
\hline $\begin{array}{c}\text { Persentase } \\
\text { Penguasaan }\end{array}$ & $\begin{array}{c}\text { Tingkat } \\
\text { Kemampuan }\end{array}$ & $\begin{array}{c}\text { Banyak } \\
\text { Siswa }\end{array}$ & $\begin{array}{c}\text { Persentase } \\
\text { Jumlah Siswa }\end{array}$ & $\begin{array}{c}\text { Rata-rata } \\
\text { Skor } \\
\text { Kemampuan }\end{array}$ \\
\cline { 1 - 4 } $90 \%-100 \%$ & Sangat tinggi & 11 & $45,8 \%$ & \\
\cline { 1 - 4 } $80 \%-89 \%$ & Tinggi & 9 & $37,5 \%$ & \multirow{2}{*}{79,2} \\
\cline { 1 - 4 } $65 \%-79 \%$ & Sedang & 4 & $16,7 \%$ & \\
\cline { 1 - 4 } $55 \%-64 \%$ & Rendah & - & - & \\
\hline $0 \%-54 \%$ & Sangat rendah & - & $100 \%$ \\
\hline
\end{tabular}

Upaya-upaya yang telah dilakukan peneliti pada siklus II telah berhasil meningkatkan kemampuan penalaran siswa. Pembelajaran yang berfokus pada siswa membuat siswa menjadi lebih berani beraktivitas dan mengemukakan ide-ide matematika. Hal ini terlihat dari bervariasinya jawaban siswa yang benar, kemampuan siswa membuat analogi dan model matematika, serta kemampuan siswa dalam menarik kesimpulan. Kemampuan penalaran matematis siswa pada siklus II mengalami peningkatan yang cukup baik dari siklus I. Banyak siswa yang mencapai ketuntasan belajar (dengan tingkat kemampuan penalaran matematis sedang, tinggi, dan sangat tinggi) pada siklus I adalah 16 siswa dengan persentase $66,6 \%$ dan pada siklus II banyaknya siswa yang mencapai ketuntasan belajar (dengan tingkat kemampuan penalaran matematis sedang, tinggi, dan sangat tinggi) mencapai 20 siswa dengan persentase $83,3 \%$. Peningkatan kemampuan penalaran matematis siswa sudah mencapai target penelitian yaitu minimal $75 \%$ dari siswa yang mengikuti tes sudah mencapai ketuntasan belajar.

\section{Pembahasan}

Penggunaan pendekatan Open-Ended dalam upaya meningkatkan kemampuan penalaran matematis siswa ditandainya dengan meningkatnya kemampuan penalaran matematis siswa. Sebelum pemberian tindakan I pada Siklus I, siswa terlebih dahulu diberikan tes awal yang bertujuan untuk mengetahui sejauh mana taraf penguasaan dan pengetahuan siswa terhadap materi prasyarat sistem persamaan linear. Dari hasil tes awal diperoleh bahwa kemampuan penalaran matematis siswa masih sangat rendah. Dari tes awal diperoleh hanya 4 siswa $(16,6 \%)$ dari 24 siswa yang mengikuti tes mencapai 


\section{Kemampuan Penalaran Matematis Siswa Kelas VIII MTs Islamiyah Medan Melalui...}

ketuntasan belajar klasikal (nilainya $\geq 75)$ sedangkan 20 siswa lainnya $(83,3 \%)$ belum tuntas.

Setelah siklus I dilakukan, terjadi peningkatan kemampuan penalaran matematis siswa. Dari pemberian tes awal diperoleh peningkatan kemampuan penalaran siswa dalam menyelesaikan soal-soal SPLDV sebesar 50\% yakni dari 16,6\% menjadi 61,6\%. Hasil tes kemampuan penalaran matematis I diperoleh 16 siswa dari 24 siswa $(66,6 \%)$ telah mencapai ketuntasan belajar klasikal (nilai $\geq 75)$ sedangkan 8 siswa lainnya $(20,8 \%)$ belum tuntas. Nilai rata-rata kelas yang diperoleh 70,8. Setelah siklus II dilakukan, terjadi peningkatan kemampuan penalaran matematis siswa. Dari pemberian tes kemampuan penalaran matematis diperoleh bahwa kemampuan penalaran matematis siswa mengalami peningkatan ketuntasan belajar sebesar $16,7 \%$ yakni dari $66,6 \%$ menjadi $83,3 \%$. Nilai ratarata kelas yang diperoleh adalah 79,2. Hasil selengkapnya dapat dilihat pada Tabel 4 berikut:

Tabel 4. Deskripsi Tingkat Kemampuan Penalaran Matematis Siswa setiap Siklus

\begin{tabular}{|c|c|c|c|c|}
\hline $\begin{array}{c}\text { Persentase } \\
\text { Penguasaan }\end{array}$ & $\begin{array}{c}\text { Tingkat } \\
\text { Kemampuan }\end{array}$ & $\begin{array}{c}\text { Tes } \\
\text { Awal }\end{array}$ & Siklus I & Siklus II \\
\hline $90 \%-100 \%$ & Sangat tinggi & - & 3 & 5 \\
\hline $80 \%-89 \%$ & Tinggi & 1 & 5 & 6 \\
\hline $65 \%-79 \%$ & Sedang & 4 & 13 & 13 \\
\hline $55 \%-64 \%$ & Rendah & 17 & 3 & - \\
\hline $0 \%-54 \%$ & Sangat rendah & 2 & - & - \\
\hline \multicolumn{2}{|c|}{$\Sigma$} & 24 & 24 & 24 \\
\hline \multicolumn{2}{|c|}{ Persentase ketuntasan klasikal } & $16,6 \%$ & $66,6 \%$ & $83,3 \%$ \\
\hline \multicolumn{2}{|c|}{ Persentase yang tidak tuntas } & $83,4 \%$ & $33,4 \%$ & $16,7 \%$ \\
\hline
\end{tabular}

Adanya peningkatan dari siklus I ke siklus II tidak terlepas dari upaya-upaya yang dilakukan peneliti, yaitu membuat kelompok belajar siswa dengan kemampuan yang heterogen dan dengan kelompok yang berbeda antara siklus I dengan siklus II. Dengan cara ini siswa lebih aktif dalam pembelajaran dan lebih mudah dalam memahami pembelajaran karena yang membantu mereka jika mengalami kesulitan adalah teman sekelompok mereka yang sudah mengerti. Tetapi jika siswa belum mengerti maka siswa akan bertanya langsung kepada guru. Dari penelitian ini, ternyata dengan penerapan pendekatan pembelajaran Open-Ended pada materi SPLDV pada kelas VIII-1 MTs Islamiyah Medan mampu meningkatkan kemampuan penalaran matematis siswa dalam menyelesaikan soal-soal SPLDV. Pendekatan pembelajaran Open-Ended ini merupakan pendekatan pembelajaran yang mengkombinasikan belajar individu dan kelompok selama kegiatan belajar mengajar berlangsung untuk mengatasi masalah-masalah matematika sehingga kemampuan penalaran matematis siswa dapat meningkat.

\section{KESIMPULAN}

Berdasarkan hasil penelitian dan pembahasan, maka diperoleh sebuah kesimpulan yaitu penerapan pendekatan pembelajaran Open-Ended dapat meningkatkan kemampuan penalaran matematis siswa kelas VIII-1 MTs Islamiyah Medan pada materi SPLDV. Setelah siklus II dilakukan, terjadi peningkatan kemampuan penalaran matematis siswa kelas VIII-1. Dari pemberian tes kemampuan penalaran matematis diperoleh bahwa kemampuan penalaran matematis siswa mengalami peningkatan ketuntasan belajar sebesar $16,7 \%$ yakni dari $66,6 \%$ menjadi $83,3 \%$. Nilai rata-rata kelas yang diperoleh adalah 79,2. Seluruh indikator keberhasilan penelitian telah terpenuhi pada siklus II sehingga 
pelaksanaan tindakan dihentikan hingga siklus II. Berdasarkan kesimpulan penelitian di atas, maka penulis memberikan beberapa saran sebagai berikut:

1. Bagi peneliti lain hendaknya dapat mengembangkan penelitian-penelitian berikutnya untuk meningkatkan indikator kemampuan penalaran matematis siswa dalam materi pembelajaran dan jenjang sekolah yang lain sehingga memberikan manfaat yang lebih besar terhadap guru dan siswa dalam pembelajaran matematika

2. Bagi siswa hendaknya mendapat bimbingan dari berbagai pihak agar kesadaran akan pentingnya kemampuan penalaran matematis dapat meningkat dan siswa juga bisa lebih aktif dalam mengikuti pembelajaran matematika

3. Bagi sekolah Pendekatan pembelajaran Open-Ended hendaknya dapat dijadikan salah satu metode sebagai landasan dalam melaksanakan pembelajaran matematika di sekolah lanjutan, karena dapat meningkatakan prestasi siswa dalam pembelajaran matematika.

\section{DAFTAR PUSTAKA}

Arikunto, S. 2006. Dasar-Dasar Evaluasi Pendidikan. Jakarta: Bumi Aksara

Depdiknas. 2006. Kurikulum Tingkat Satuan Pendidikan. Jakarta: Balitbang Depdiknas.

Hino, K. 2007. Toward the problem-centered classroom: trends in mathematical problem solving in Japan.

http://cimm.ucr.ac.cr/ciaemIngles/articulos/universitario/conocimiento/Toward $\% 20$ the $\% 2$ Oproblem-

centered\%20classroom:\%20trends\%20in\%20mathematical\%20problem\%20solving \%20in\%20Japan*Hino,\%20Keiko\%2 0*Keiko\%20Hino.pdf

Lestari, P. D., Dwijanto, D., \& Hendikawati, P. 2016. Keefektifan Model Problem-Based Learning Dengan Pendekatan Saintifik Terhadap Kemampuan Pemecahan Masalah Dan Kemandirian Belajar Peserta Didik Kelas Vii. Unnes Journal of Mathematics Education, 5(2).

NCTM. 2000. Principle and Standards for School Mathematics. Reston VA: NCTM.84.

Pehkonen, E. 1999. Open-ended problems: A method for an educational change. Makalah disajikan dalam 4 Pan-Hellenic Conference with International Participation Didactics of Mathematics \& Informatics in Education, di The University of Crete: Department for Primary Education, Department of Computer Science, Department of Mathematics.

Rosnawati, R. 2011. Kemampuan penalaran matematika siswa SMP Indonesia pada TIMSS 2011. Prosiding Seminar Nasional Penelitian, Pendidikan dan Penerapan MIPA.

Sagala, S. 2011. Konsep dan Makna Pembelajaran. Bandung: Alfabeta.

Shimada, S., \& Becker J.P. 1997. The Open-Ended Approach. A New Proposal for Teaching Mathematics. Virginia: NCTM

Sumartini, T. S. 2015. Peningkatan Kemampuan Penalaran Matematis Siswa melalui Pembelajaran Berbasis Masalah. Jurnal Pendidikan Matematika. Volume 5, Nomor 1.

Turmudi. 2008. Landasan Filsafat dan Teori Pembelajaran Matematika Siswa dalam Pelajaran Matematika. Disertasi doktor pada PPS IKIP Bandung: Tidak dipublikasikan.

Wahyudin. 2008. Pembelajaran dan Model-Model Pembelajaran. Bandung: UPI 